\title{
バイオチップの走査型電気化学顕微鏡解析
}

\author{
安川智之*, 珠玖 仁**, 水谷文雄 ${ }^{* *}$, 末永智一** \\ *兵庫県立大学 大学院物質理学研究科 (T678-1297 兵庫県赤穂郡上郡町光都 3-2-1) \\ **東北大学 大学院環境科学研究科 (T980-8579 宮城県仙台市青葉区荒巻字青葉 6-6-11)
}

\section{Sensing System for Bioassay Based on Scanning Electrochemical Microscopy}

Tomoyuki YASUKAWA*, Hitoshi SHUKU**, Fumio MIZUTANI* and Tomokazu MATSUE**

*Graduate School of Material Science, University of Hyogo (3-2-1, Kouto, Kamigori-cho, Ako-gun, Hyogo 678-1297)

**Graduate School of Environmental Studies, Tohoku University(6-6-11, Aoba, Aramaki, Aoba-ku, Sendai-shi,

Miyagi 980-8579)

Keywords : SECM Imaging, Cellular Activity, Single Cell Analysis, Biochip

\section{1.はじめに}

マイクロ電極は表面化学やバイオ分析化学の分野で活躍し ている。走查型電気化学顕微鏡 $(\mathrm{SECM})$ は, 1980 年代の後 半に表面・界面の局所領域で進行する化学反応および生体化 学反応を評価および可視化する新規技術として導入され た ${ }^{1) 3)}$ 。電気化学活性種を検出可能なマイクロ電極をプロー ブとした SECM を用いると局所領域における電気化学活性 種の濃度変化をリアルタイムで計測し, 電気化学活性種の空 間的な濃度プロファイルをイメージとして取得できる。現在, SECM は広範囲の分野に応用されており, 局所領域で進行 する化学反応を定量的に評価できるシステムとして高く評価 されている。走査型プローブ顕微鏡の代表である走査型トン ネル顕微鏡や走査型原子間力顕微鏡の有する原子レベルの空 間分解能と比較して, 近年改良が進んでいるが SECM の空 間分解能は極めて低い。この低い空間分解能の原因は, 化学 反応が進行している位置から電極プローブへの電気化学活性 種の拡散にある。しかし, マイクロ電極のサイズが単一細胞 測定やバイオチップの評価のために一致し, サンプルを破壊 することのない非侵襲姓を有しているため，この分野におい て多用されるようになった。SECM は電極の走査方法にお いて高さ一定モードと距離一定モードに大別され, 電流の計

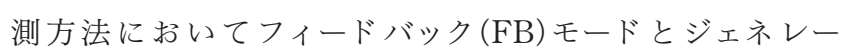
ションーコレクション $(\mathrm{GC})$ モードに大別され, これらは総 説や書籍に紹介されている(4) 8)。高さ一定モード SECM は, 比較的簡便な装置で計測可能でありバイオチップの評価ツー ルとして使用されている。高さ一定モードの欠点を補い, 高 低差の大きなサンプルである単一細胞の機能を高感度に多方 面から解析する目的で距離一定モード SECM が開発されて いる。しかし, 距離一定モード SECM は, プローブの作製, 距離制御機構および走査モードなどにおいて開発途上であり, 現在でも細胞評価に高さ一定モード SECM が活躍している。
本解説では， 2 および 3 章において，ネガティブ FB モード SECM およびポジティブ FB モード SECM の測定原理につ いて解説し, 単一細胞の形状イメージングと抗体チップの評

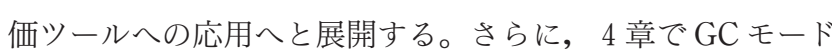
SECM の測定原理を解説するとともに, 細胞をセンサ素子 とした薬物センサや薬剤スクリーニングへの SECM の適用 について述べる。最後に, 微細加工技術を利用して作製した 微生物や細胞アレイチップの検出ツールとして, 高さ一定 モードSECM を応用した例について我々の研究を中心に紹 介したい。

\section{2. ネガティブフィードバック (FB) モード SECM}

SECM ではマイクロ電極を 3 次元的に駆動可能な XYZ ス テージおよびピエゾ駆動のポジショナーに取り付けサンプル へと近接させる。電極をサンプル近傍で走査し電気化学反応 を検出することにより, 表面の凹凸情報や化学的および生物 化学的な反応を画像化する。一般的に, 溶液中に介在させた 電気化学活性種の酸化還元電流は拡散支配的であるため, 表 面近傍で得られる電流は電極先端一表面間距離に依存する。 $\mathrm{FB}$ モードの理論は, Markinらによって報告されてい $3^{9,10)}$ 。図 $1 \mathrm{a}$ に, 電極一表面間距離に対する酸化還元電流 応答を示す。電極が基板表面から離れておりバルク溶液中に ある場合には, 電気化学活性種の定常拡散層が電極先端から 溶液層に半球状に形成され， $\mathrm{i}_{\mathrm{T}, 8}=4 \mathrm{nFDCA}$ で表される定常 電流 $\left(\mathrm{i}_{\mathrm{T}, 8}\right)$ が観測される。ここで, $\mathrm{n}$ は反応電子数, $\mathrm{F}$ は ファラデー定数, $\mathrm{D}$ は電気化学活性種の拡散定数, $\mathrm{C}$ は電気 化学活性種のバルク濃度, A は電極半径を表している。電 極を絶縁性基板に近接させると, バルクから電極表面への電 気化学活性種の輸送が絶縁性基板によって阻害され通常の半 球状拡散層が形成できないため電流 $\left(\mathrm{i}_{\mathrm{T}}\right)$ は電極一基板表面間 距離の減少とともに減少する。これがネガティブ FB 効果で ある。電極位置一電流曲線(図 1 a) を用いると電極の $z$ 方向 
位置情報を得ることができる。電極と表面の衝突は, 電極お よび表面の双方にダメージを与える可能性が高いため，ネガ ティブ FB モードを利用した $z$ 方向距離制御は有効である。 また，電極を絶対的な高さを一定に保ち xy 方向に走査する と基板の凹凸に応じて電極一基板間距離が変化するため，そ の際に生じる電流応答の変化から凹凸をイメージングできる。 ネガティブ FB モードを用いると単一細胞の形状をイメー ジングできる ${ }^{11,12)}$ 。平板基板上に培養された細胞の存在によ り, 電極一細胞間の距離が変化するため FB 効果により細胞 形状を電流として捉えることが可能になる。しかし, 溶液中 に介在させるメディエータの選択に注意する必要がある。す なわち，メディエータは細胞膜を透過しないことが必要であ る ${ }^{13)}$ 。図 2 に, ネガティブ FB 効果を利用した単一細胞の形 状イメージを示す。マイクロ電極で溶液中のメディエータ $\left(\mathrm{Fe}(\mathrm{CN})_{6}{ }^{4-}\right)$ を酸化すると, 電極表面近傍に半球状の拡散層 が形成される。この状態で電極を細胞表面に近接させると電 流はバルク中と比較して減少する。この電流の減少は, メ ディエータの物質移動が, マイクロ電極と細胞膜の接近にと もない空間的に抑制されるためである。しかし, 電極が細胞 から遠ざかると拡散妨害効果 (ネガティブ FB 効果)が小さく なり電流応答が増加する。よって, 細胞の形状イメージング にはメディエータの膜透過性が応答に大きく影響を与える。 細胞膜透過性は, メディエータの親・疎水性, 大きさおよび 電荷に大きく依存する。一般的に, $\mathrm{Fe}(\mathrm{CN})_{6}{ }^{3-14-}, \mathrm{Ru}$ $\left(\mathrm{NH}_{3}\right)_{6}{ }^{3+/ 2+}, \mathrm{Ru}(\mathrm{CN})_{6}{ }^{3-/ 4-}$ のような金属錯体メディエー夕 は, 電荷を有し親水性が高いため細胞膜の透過性が低い。 よって, これらのメディエータは, 細胞の形状イメージを得 るために適している。しかし, メディエータとして膜透過性 の大きなキノン類を使用すると，ネガティブ FB 効果が小さ く, 細胞内で電子授受を行うため形状を得ることが困難であ る。さらに, 形状イメージを得るためには, メディエータが 細胞に毒性を示さないこと, メディエータの刺激により細胞 活性が変化しないことが重要である。

神経細胞の機能を研究するためにモデルとしてよく使用さ れている PC 12 の形状がネガティブ FB モード SECM を用
いてイメージングされている ${ }^{14)}$ 。膜透過性が小さく細胞毒性 の低い $\mathrm{Ru}\left(\mathrm{NH}_{3}\right)_{6}{ }^{3+}$ が PC 12 の形状イメージングに用いら れている。PC 12 は, 成長因子の存在下で細胞体から神経突 起をのばすことが知られている。この神経突起の構造は, 光 学顕微鏡で観察することが困難であるが, ネガティブ FB モード SECM を用いて明確に可視化されている。局所領域 における神経突起の高さの差をイメージとして捉えることが 可能である。しかし, SECM イメージングでは, 電極とサ ンプルの衝突を避けるために, イメージング領域のサンプル の中で最も高い位置のさらに数 $\mu \mathrm{m}$ 上方にマイクロ電極を 設置しなければならない。PC 12 では, 細胞体の上に電極を 設置する必要がある。それゆえ, 1 フレームの中に神経突起 を含む細胞全てをイメージングできない。ネガティブ FB 効 果は, 電極一サンプル間距離の増加にともない急激に減少す る(図 1 )。よって, 電極から $10 \mu \mathrm{m}$ 程度離れた細胞突起の 形状を得ることは困難である。そこで, 細胞の形状を詳細に イメージングするために電極一サンプル間距離を制御した距 離一定モード SECM が開発されている15) 18)。

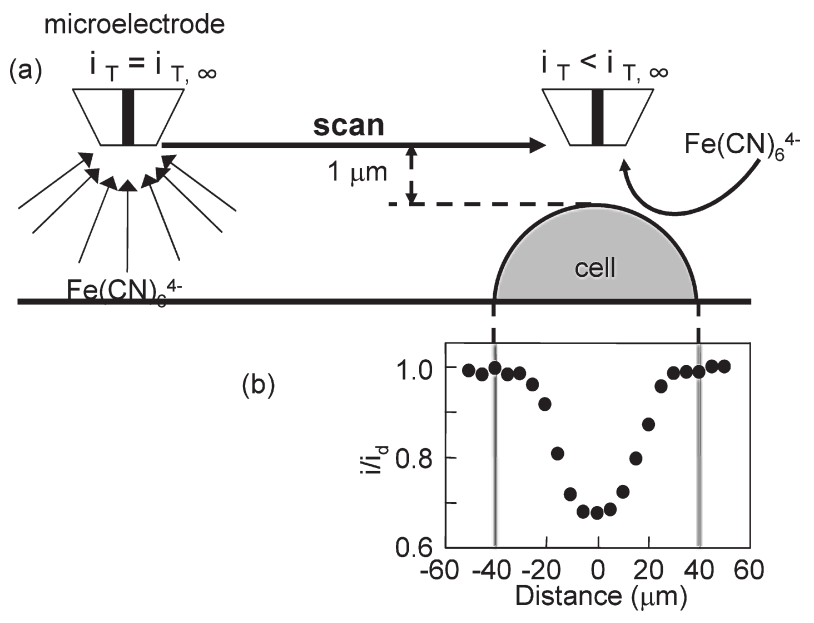

図 2 ネガティブFB モード SECM を用いた細胞形状のイメー ジング

（a）形状イメージングの模式図。（b）x 方向距離に対す るフェロシンアンイオンの酸化電流応答。

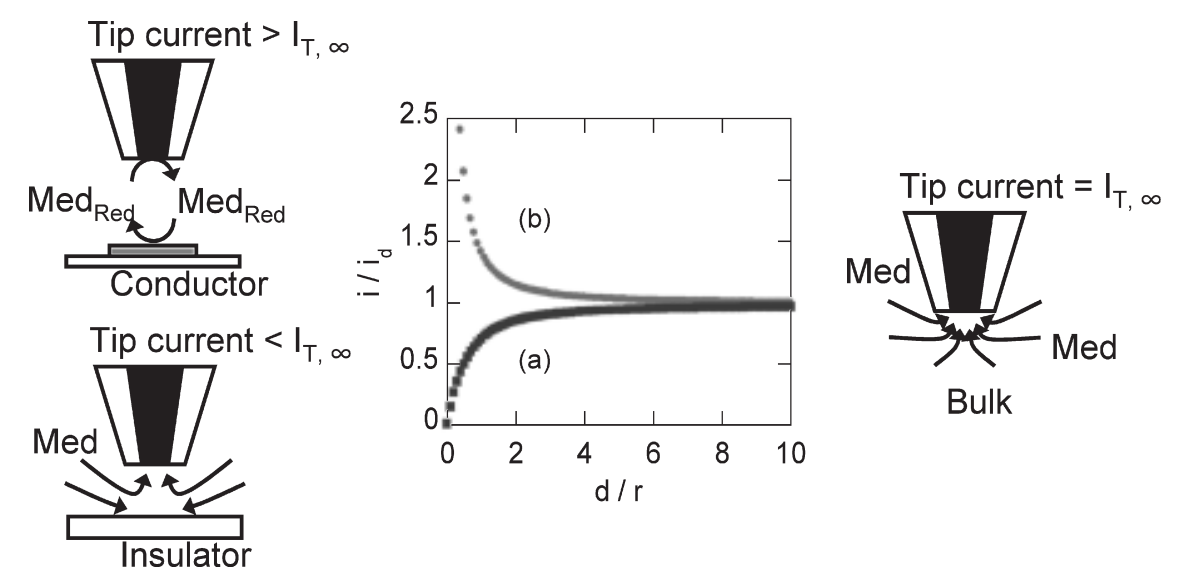

図 1 マイクロ電極一基板間距離に対する電流応答。マイクロ電極を(a) 絶縁性基板および (b) 導電性基板に近接させた場合。 $\mathrm{d}$; 電極一基板間距離， $\mathrm{r}$; 電極半径， $\mathrm{i}$; マイクロ電極で観測された電流， $\mathrm{i}_{\mathrm{d}}$; バルク 中で観測される酸化還元電流, Med；メディエータ 


\section{3. ポジティブフィードバック (FB) モード SECM}

一方，マイクロ電極を金属平板のような導電性基板に近接 させた場合, 電流は電極一基板間距離の減少にともなって増 加する(図 1 b)。マイクロ電極において酸化反応により生成 された電気化学活性種の酸化体は, 拡散により導電性基板に 到達し還元される。さらに, この再生された還元体はマイク ロ電極に到達して再酸化されるレドックスサイクリングが進 行するためマイクロ電極で得られる電流応答は増幅される。 これが，ポジティブ FB 効果である。

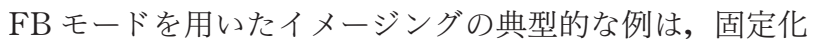
酵素の活性イメージングである。たとえば, 固定化されたグ ルコースオキシダーゼ(GOx)の活性イメージングが行われ ている(図 3 ) ${ }^{19}$ )。走査するマイクロ電極で還元型メディエー 夕 $\left(\mathrm{Med}_{\mathrm{R}}\right)$ を酸化すると酸化体 $\left(\mathrm{Med}_{\mathrm{O}}\right)$ が生成する。拡散し 固定化 GOx に到達した $\mathrm{Med}_{\mathrm{o}}$ は GOx の電子受容体として 作用すると，グルコースが酸化される際に GOx から電子を 受け取りもとの $\operatorname{Med}_{R}$ へ還元される。さらに, GOxで再 生された $\operatorname{Med}_{\mathrm{R}}$ はマイクロ電極へと拡散し再び酸化される。 1 分子のメディエータが電極一基板間を何度も往復するため, マイクロ電極での応答は増大寸る。これが, 酵素反応を利用 したポジティブ FB 効果である。マイクロ電極を xy 方向に 移動させ, 酵素の固定されていない絶縁性基板に達すると, ネガティブ FB 効果によりバルクから電極表面へのメディ エータの拡散が抑制されるため，検出される電流は減少する。 両方の効果を有効に利用し電極を走查して電流を 2 次元マッ ピングすると基板表面で進行する酵素反応を SECM イメー ジとして得ることができる。この技術は，基板上にパターン 化された酵素や酵素センサ表面の評価に極めて有効である。 また，他の酵素のイメージングもこの手法を用いて行われて いる。中でも，ニコチンアミドアデニンジヌクレオチド $(\mathrm{NADH})$ 酸化酵素であるジアフォラーゼの活性評価は実用 的にきわめて重要である。300 種類以上ものデヒドロゲナー ゼが $\mathrm{NAD}^{+}$を電子受容体として作用するため，ジアフォ ラーゼとこれらの酵素と組み合わせることにより多種多様な センサを構築することが可能になる ${ }^{20)}$ 。

ポジティブ FB モード SECM は，基板上に抗体を集積化 した抗体アレイチップの検出に応用することができる21) 24)。 基板表面上に作製した抗体アレイに測定対象物質および酵素 標識抗体を反応させる。捕捉された酵素量はサンプル溶液中 に含まれていた測定対象物質の濃度に依存するため，抗体久 ポット上の酵素活性を調査することにより検出が可能となる。

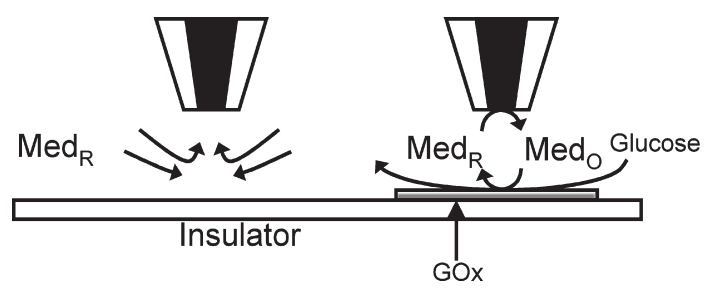

図3 ポジティブ FB モード SECM を用いた固定化グルコース オキシダーゼ活性のイメージング
標識酵素には，アルカリフォスファターゼ，ペルオキシダー ゼ(HRP)，GOxなどがよく利用される。ポジティブ FB モード SECM は，メディエータが電極一酵素間でサイクル する増幅系であるため, 検出シグナルが大きく測定対象物質 の高感度測定が可能になる。また，抗体アレイを用いること により，複数種類の分子を同時に検出することができる。

\section{4. ジェネレーションーコレクション $(\mathrm{GC})$ モード SECM}

表面から生成される化学物質をマイクロ電極で検出する方 法は, GC モード SECM と呼ばれている。GC モード SECM は, 細胞から放出される生物学的に重要な物質の調 查に用いられ ${ }^{25)}$, 細胞の機能を利用したバイオチップの構築 に応用されている。個々の細胞の機能や活性の評価から始ま り，そのイメージングおよび外部刺激に対する応答について 調査されており, 細胞および微生物チップの評価系に組み込 まれている。

単一植物細胞の光合成および呼吸による酸素の放出および 吸収を定量的に評価し, 電極を 2 次元に走査することにより 光合成抢よび呼吸活性のイメージングを行うことができ

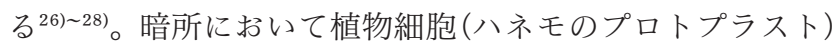
は $2.0 \times 10^{-14} \mathrm{~mol} / \mathrm{s}$ で呼吸により酸素を消費する。一方, 光を照射すると細胞は光合成により酸素を放出する。酸素生 成速度は光強度の増加にともなって増加し, $15 \mathrm{kLx}$ 以上の 光強度で酸素放出速度は $7.5 \times 10^{-14} \mathrm{~mol} / \mathrm{s}$ に到達し飽和し た。単一細胞近傍の酸素濃度プロファイルを計測することに より, 酸素の消費および生成速度を定量的に評価することが 可能である。また, 細胞近傍の酸素還元電流をマッピングす ることにより単一細胞の呼吸抒よび光合成活性をイメージン グできる。図 4 に, 単一植物細胞の呼吸および光合成活性の SECM イメージを示す。これらのイメージは同じ植物細胞 を対象に暗所下および明所下において得ている。暗所下にお いては, 細胞の近傍で酸素還元電流の小さいイメージが得ら れており, 細胞が呼吸により酸素を吸収していることがわか る。一方, 明所下では細胞近傍の酸素還元電流が大きく, 光 合成により酸素が生成されていることを示している。また， 複数の植物細胞を同時にイメージングすることも可能であ る ${ }^{29)}$ 。片方の細胞に光合成電子伝達鎖の阻害剤であり農薬の 一種である $3(3,4$-ジクロロフェニル)-1,1-ジメチル尿素 (DCMU)をインジェクションすると, DCMU を注入した細 胞の光合成活性が迅速に低減する結果を得た。よって, これ は細胞を利用した薬物センサおよび薬剤スクリーニングに応 用可能であることがわかる。酸素還元電流を指標とした単一 がん細胞の呼吸活性評価およびシアン化物イオンの膜透過性 の評価も行われている30)。また, パターン配列された細胞の 呼吸活性も評価されている。コンタクトプリンティングを用 いて疎水性基板に細胞外マトリックスやフィブロネクチンの パターンを作製し, 細胞を培養することにより細胞パターン 培養が行われている311。バンド状に配列された HeLa 細胞の 活性は島状に配列された細胞の活性と比較して大きいことが 示されている。バンド状に配列された細胞はある程度自由に 広がって基板に接着しているが，小さな島状に配列された細 
胞の形状は接着面積が不足しているため球状に制限されてい る。細胞の活性を利用したバイオアッセイシステムを構築す るためには, 細胞の形状の変化に起因する細胞活性の差は極 めて重要であるため, SECM による細胞チップの活性評価 が有効であることがわかった。

GC モード SECM を用いると細胞のレドックス活性をイ メージングできる ${ }^{32)}$ 。GC モード SECM では，溶液中に介 在させた酸化型メディエータが細胞により還元され細胞外に 放出される還元体を検出する。酸化型メディエータであるべ ンゾキノン $(\mathrm{BQ})$ は, 細胞膜を透過することができ, 細胞内 の光合成電子伝達鎖および呼吸鎖から 2 つの電子を受け取っ てハイドロキノン $\left(\mathrm{QH}_{2}\right)$ へと還元される。図 5 は, 単一細 胞近傍における $\mathrm{QH}_{2}$ の酸化電流応答である。暗状態から植 物細胞に光を照射すると, $\mathrm{QH}_{2}$ の酸化電流は急激に増加し 一定に達する。また，暗状態に戻すと電流はもとのレベルに 戻る。一方, $\mathrm{BQ}$ の酸化電流は光照射により減少する。光照 射下において, BQ は細胞に取り込まれ, 光合成電子伝達鎖 から電子を受け取り $\mathrm{QH}_{2}$ へと還元され, 生成した $\mathrm{QH}_{2}$ は
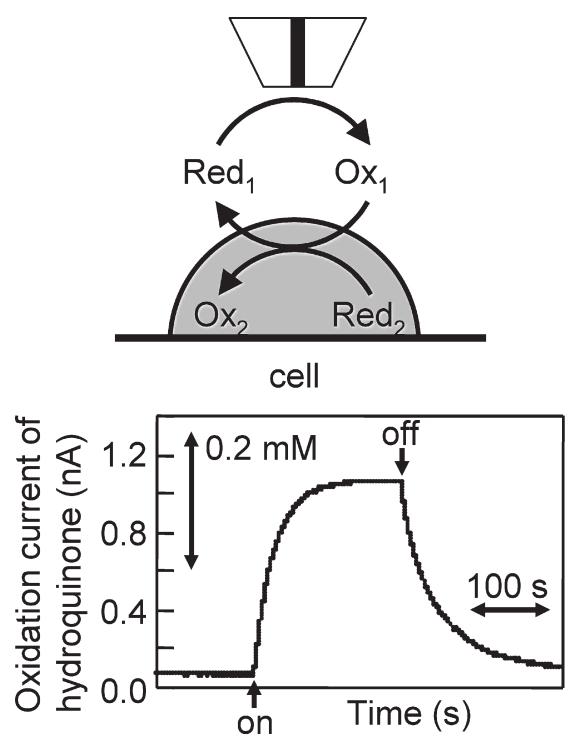

図 5 単一細胞から放出されるヒドロキノンの酸化電流の経時変 化
細胞外へと放出されることを示している。SECM を用いる と単一細胞が放出, 吸収する化学物質の経時変化をリアル夕 イムで計測することが可能になる。

近年，Markin らのグループは，GC モード SECM を用い た動物細胞やバクテリアのレドックス活性の評価を行ってい る。SECM を用いて細胞内で進行するメディエータの再生 反応をマッピングしている。細胞外液に加えられたメナジオ ン, 1,2 -ナフトキノン, $\mathrm{BQ}, \mathrm{N}, \mathrm{N}, \mathrm{N}^{\prime}, \mathrm{N}^{\prime}$-テトラメチル -1,4-フェニレンジアミン (TMPD) のような疎水性のメディ エータの細胞による再生輸送反応が SECM を用いて検出さ れた。メディエータの反応速度定数や細胞膜透過係数のよう な細胞特性が, 単一細胞にマイクロ電極を近接させることに より評価された。SECM を用いると正常細胞と腫瘍細胞で レドックス活性の差を検出することができるので, 培養血中 の細胞の中から正常細胞と腫瘍細胞を区別することが可能で ある。よって, この手法は薬剤のスクリーニングやがん診断 に有用である。

\section{5. 微生物・細胞チップ}

上述したSECM を用いる細胞機能および活性の評価手法 をバイオアッセイの検出システムとして利用している。細胞 の培養技術, 微細加工によるチップの三次元加工技術および 細胞の配列化技術の進展とともに, 基板上に微生物や細胞を 集積固定化したチップが開発されている。たとえば, 微生物 チップのグルコース検出のために SECM が利用されてい る33),34)。基板上のマイクロ孔内にコラーゲンゲルに包埋した 大腸菌をスポットし微生物チップを作製している。大腸菌の 呼吸活性は, 微生物から生成されるフェロシアンイオンを SECM で検出して評価している。溶液中に介在させたフェ リシアンイオンは細胞膜を透過し, 呼吸鎖から電子を受け 取ってフェロシアンイオンに還元され細胞外へと放出され拡 散する。固定化されている大腸菌から生成されるフェロシア ンイオンの量は細胞の呼吸活性に依存する。溶液中にグル コースを添加すると, 細胞の代謝活性が増加するため固定化 大腸菌から生成されるフェロシアンイオンの量も増加する。 よって, 微生物チップはグルコースやアルコールなどの栄養

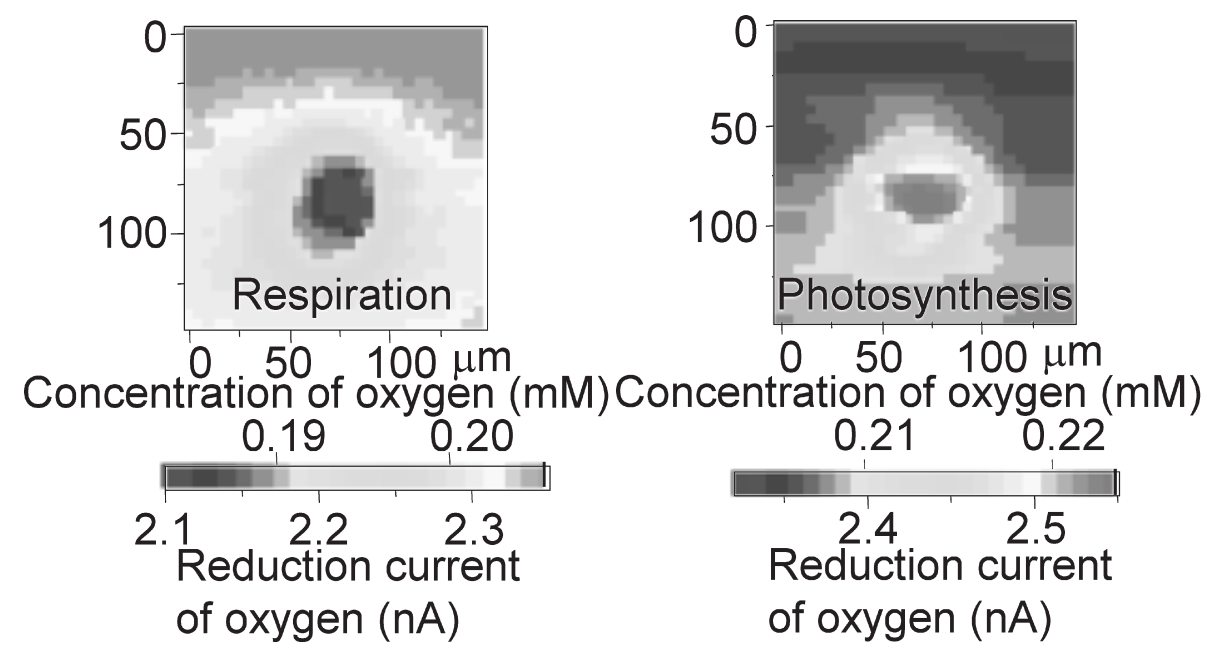

図 4 GC モード SECM を用いた単一植物細胞の呼吸および光合成活性のイメージング 
素を検出するためのセンサとして利用可能である。また, 微 生物チップを用いた SECM は，生体や環境への毒性物質の 検出に用いることができる。 SECM を用いるとマイクロ孔 内に固定化された微生物の増殖挙動をモニタリングできるた め, 微生物の同定, 薬剤スクリーニングおよび細胞工学に応 用することが可能になる。近年では，微生物の遺伝子発現の 検出にも微生物チップを用いた SECM を応用している ${ }^{35)}$ 。

細胞をチップ上に集積した細胞チップを用いて制がん剂感 受性評価を行っている ${ }^{36)}$ 。ヒトがん細胞株をコラーゲンに包 埋し，チップ上の微細貫通孔に固定する。コラーゲンは細胞 外マトリックスの主成分であり，現在使用されている制がん 剤感受性試験においても細胞培養に利用されている。コラー ゲン包埋培養による細胞の増殖速度は, 通常のフラスコ内培 養と比較して遅くin vivoに近い。よって，この培養方法は 生体内における増殖挙動を比較的再現しておりアッセイに有 利である。図 6 に，細胞チップおよびその SECM イメージ を示す。細胞としてヒト赤白血球細胞株 (K 562, 写真左) お よびアドリアマイシン耐性細胞株（K 562/ADM，写真右)を 固定化し，制がん剤としてアドリアマイシンを作用させた際 の細胞の呼吸活性を評価した。SECM イメージでは，細胞 と一致した位置に 2 つの電流スポットが観測された。この電 流の減少は, 細胞の呼吸による酸素濃度の減少に起因する。 $1 \mu \mathrm{M}$ のアドリアマイシンを細胞チップに投与し 3 日間培養 後の SECM イメージでは, K 562/ADM の呼吸活性が K 562 と比較して高くなった。K 562 細胞はアドリアマイシ ンにより増殖を阻害されるが，K 562/ADM 細胞は増殖する ことが示された。これは, 複数の細胞種に対する薬剤感受性 を同時に継続的に行えることを示している。

また，細胞チップにマイクロ流路を組み合わせることによ り，複数種類の薬剤の効果を同時に評価できる(図 7$)^{37), 38)}$ 。 たとえば， $4 \times 5$ の微細貫通孔アレイを有する基板に 4 本の (a) K562 K562/ADM

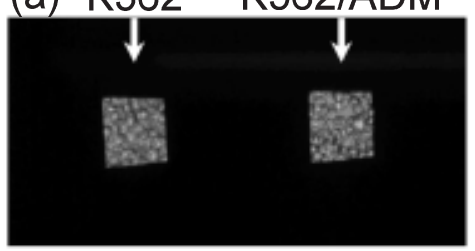

(b)

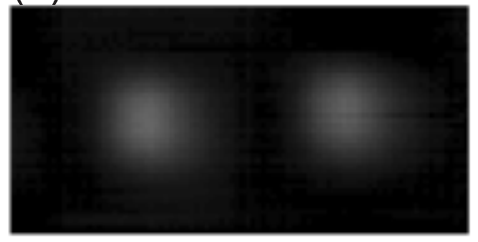

(c)

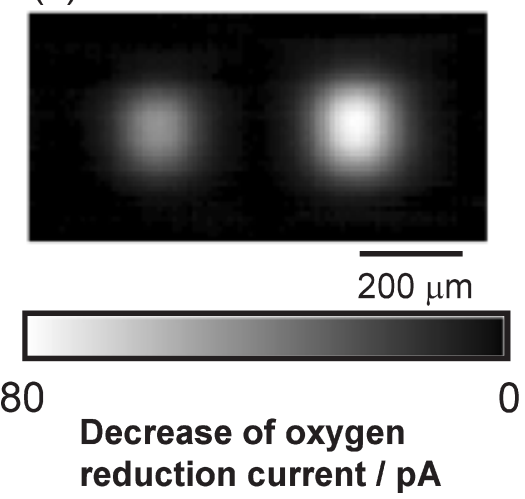

図 6 細胞チップおよびその SECM イメージ

（a）微細貫通孔にコラーゲンゲル包埋法により集積化さ れた細胞チップ。左：K 562 細胞，右：アドリアマイシ ン耐性 K 562 細胞。(b) 細胞チップの呼吸活性に基づく SECM イメージ。(c) $1 \mathrm{mM}$ アドリアマイシンを含む培 地中で 3 日間培養後の SECM イメージ。

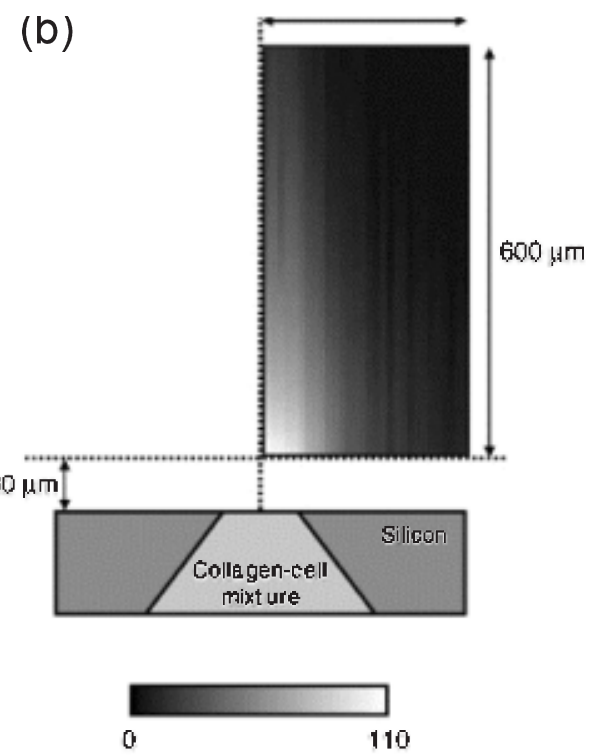

Relative reduction current / $\mathrm{pA}$

図 7 微細孔アレイとマイクロ流路を組み合わせた細胞アレイチップの作製とSECM を用いた複数種類の薬剤効果評価システム

（a）マイクロ流路を用いた細胞アレイチップの概念図。上：デバイスの断面図，左：流路の上面図，右：微細貫通孔アレイの写真。 流路のサイズ : $700 \mathrm{~mm} \times 10 \mathrm{~mm}$ ，微細貫通孔；一辺 $450 \mathrm{~mm}$ 。(b) 細胞チップ上の呼吸活性に基づく SECM イメージ。 
マイクロ流路を組み合わせている。微細貫通孔にはヒト乳が ん由来細胞株 (MCF-7) を固定化し，4 本の流路に違う種類 の制がん剤を投与する。そして, 所定時間培養後に細胞の呼 吸活性を SECM で計測する。貫通孔を用いているので, 制 がん剤投与に利用した流路を下側に配置すると, 流路を構成 するパーツを除去することなく 1 枚のチップを経時的に SECM 計測できる。SECM 計測の際には, 電極を $\mathrm{z}$ 方向に 走査し細胞チップ近傍の酸素濃度プロファイルを測定する (図 7 b)。酸素濃度は細胞集積化微細孔からの距離の逆数に 比例するため, その直線性から高精度に細胞活性を計測でき る。3 種類の制がん剤 (cisplatin, 5-fluorouracil, paclitaxel)をそれぞれ流路に導入し，24 時間薬剤接触培養を 行った。1 本の流路は制がん剂を含まない培地を導入しコン トロールとして使用した。接触培養後, 経時的に細胞の活性 を SECM 計測すると, paclitaxel が細胞活性を抑制し MCF -7 に対して効果的に作用する制がん剤であることがわかっ た。他の一般的に用いられている細胞活性評価法を用いても 薬剤効果に同様の傾向が観測されるため，細胞チップの SECM 計測法が薬剤スクリーニングにおいて有効であるこ とが示された。

\section{6. おわりに}

本解説では, SECM の測定モードにおける測定の特長に ついて述べ，その測定技術を利用したバイオチップの評価シ ステムへの応用へと展開した。ネガティブ FBモード SECM では, マイクロ電極と測定対象物質の空間的な接近 によるメディエータの拡散阻害現象を利用した細胞の形状イ メージングおよびメディエータの細胞膜透過性の評価が可能 である。ポジティブ FB モード SECM では, 固体基板上に 固定化された酵素反応と電極反応間において進行するメディ エータのレドックスサイクリングを用いた, 酵素センサの評 価や免疫測定への応用について述べた。さらに，GCモード SECM を用いると, 単一細胞により放出または吸収される 物質のリアルタイムモニタリングおよびイメージングが可能 である。さらに, この検出方法は, 微生物チップや細胞チッ プの評価法として応用可能であることを紹介した。SECM が細胞の活性評価法として極めて有効であることが示されて おり, 今後, 実用的な薬剤スクリーニングシステムの開発へ の展開が期待される。

現在, SECM は高感度, 高分解能計測を行うために, 本 解説で紹介した高さ一定モード SECM から距離一定モード $\mathrm{SECM}$ て開発が進んでいる。この手法を用いると, 細胞 一サンプル間距離を $100 \mathrm{~nm}$ 以下に保持しサンプルの凹凸に 沿って電極の $Z$ 方向位置を制御できるため, サンプル形状と 電気化学情報を同時に高感度に取得できる。また, 光ファイ バ電極を使用することにより，3 系同時計測が可能な多機能 型 SECM の開発も進めている。このような, SECM 装置の 改良抢よび多機能化の進展とともに, 医療, 環境分野に打け る高性能センシングシステムとしての発展を期待している。

(2008-9-29 受理)

\section{文献}

1) R. C. Engstrom, M. Weber, D. J. Wunder, R. Burgess and S. Winquist ; Anal. Chem., 58, 844 (1986).

2) A. J. Bard, F.-R. F. Fan, J. Kwak and O. Lev; Anal. Chem., 61, 132 (1989).

3 ) R. C. Engstrom and C. M. Pharr ; Anal. Chem., 61, 1099 A (1989).

4 ) G. Wittstock ; Fresenius J. Anal. Chem., 370, 303 (2001).

$5)$ G. Nagy L. Nagy; Fresenius J. Anal. Chem., 366, 735 (2000)

6 ) M. V. Mirkin and B. R. Horrocks ; Anal. Chim. Acta, 406, 119 (2000).

7 ) B. Horrocks and G. Wittstock ; Scanning Electrochemical Microscopy, p. 445 (Marcel Dekker, N. Y., 2001).

8 ) H. Shiku, H. Ohya and T. Matsue ; Bioelectrochemistry, p. 257 (Wiley-VCH, 2002)

9 ) M. V. Mirkin ; Scanning Electrochemical Microscopy, p. 145, (Marcel Dekker, Inc, 2001).

10) A. J. Bard. F.-R. F. Fan and M. V. Mirkin; Electroanalytical Chemistry, Vol.18, p. 243, (Marcel Dekker, Inc, 1994).

11) T. Yasukawa, T. Kaya and T. Matsue ; Electroanalysis, 12, $653(2000)$.

12) T. Yasukawa, T. Kaya and T. Matsue; Anal. Chem. 71, 4637 (1999).

13) T. Yasukawa, I, Uchida and T. Matsue; Biochim. Biophys. Acta, 1369, 152 (1998).

14) J. M. Liebetrau, H. M. Miller, J. E. Baur, S. A. Takacs, V. Anupunpisit, P. A. Garris and D. O. Wipf ; Anal. Chem., 75, 563 (2003).

15) D. Oyamatsu, Y. Hirano, N. Kanaya, Y. Mase, M. Nishizawa and T. Matsue; Bioelectrochemistry, 60, 115 (2003).

16) H. Yamada, H. Fukumoto, T. Yokoyama and T. Koike ; Anal. Chem., 77, 1785 (2005).

17) H. Yamada, M. Ogata and T. Koike ; Langmuir, 22, 7923 (2006).

18) A. Hengstenberg, A. Blochl, I. D. Dietzel and W. Schuhmann; Angew. Chem. Int. Ed., 40, 905 (2001).

19) D. T. Pierce, P. R. Unwin and A. J. Bard ; Anal. Chem., 64, 1795 (1992).

20) H. Shiku, T. Takeda, H. Yamada, T. Matsue and I. Uchida ; Anal. Chem., 67, 312 (1995).

21) H. Shiku, T. Matsue and I. Uchida ; Anal. Chem., 68, 1276 (1996).

22) H. Shiku, Y. Hara, T. Matsue, I. Uchida, T. Yamauchi ; J. Electroanal. Chem., 438, 187 (1997).

23) S. Kasai, A. Yokota, H. Zhou, M. Nishizawa, K. Niwa, T. Onouchi and T. Matsue; Anal. Chem., 725761 (2000).

24) T. Yasukawa, Y. Hirano, N. Motochi, H. Shiku and T. Matsue ; Biosens. Bioelectron., 22, 3099 (2007).

25) E. R. Travis R and M. Wightman; Annu. Rev. Bioph. Biom., 27, 77 (1998).

26) T. Yasukawa, I. Uchida and T. Matsue ; Denki Kagaku, 66, 660 (1998).

27) T. Yasukawa, T. Kaya and T. Matsue ; Electroanalysis, 12, $653(2000)$.

28) T. Yasukawa, T. Kaya and T. Matsue ; Anal. Chem., 71, 4637 (1999). 
29) T. Yasukawa, T. Kaya and T. Matsue ; Chem. Lett., 975 (1999).

30) T. Yasukawa, Y. Kondo, I. Uchida and T. Matsue ; Chem. Lett., 767 (1998).

31) M. Nishizawa, K. Takoh and T. Matsue ; Langmuir, 18, 3645 (2002).

32) T. Yasukawa, I. Uchida and T. Matsue ; Biophys. J., 76, 1129 (1999).

33) T. Kaya, K. Nagamine, D. Oyamatsu, M. Nishizawa and T. Matsue ; Electrochem., 71, 436 (2003).
34) T. Kaya, K. Nagamine, D. Oyamatsu, H. Shiku, M. Nishizawa and T. Matsue ; Lab. Chip, 3, 313 (2003).

35) K. Nagamine, S. Onodera, Y. Torisawa, T. Yasukawa, H. Shiku and T. Matsue; Anal. Chem., 77, 4278 (2005).

36) Y. Torisawa, T. Kaya, Y. Takii, D. Oyamatsu, M. Nishizawa and T. Matsue; Anal. Chem., 75, 2154 (2003).

37) Y. Torisawa, H. Shiku, S. Kasai, M. Nishizawa and T. Matsue; Int. J. Cancer, 109, 302 (2004).

38) Y. Torisawa, H. Shiku, T. Yasukawa, M. Nishizawa and T. Matsue ; Secs. Actuat. B, 108, 654 (2005). 